\title{
THE PHONOLOGICAL SYSTEM OF BALINESE LANGUAGE ON TEGALLINGGAH SPOKEN BY MOSLEM PEOPLE: A DESCRIPTIVE QUALITATIVE STUDY
}

\author{
G.A.A.P. Naraswari ${ }^{1}$, I.G. Budasi ${ }^{1}$, N.K. Wedhanti ${ }^{2}$ \\ Jurusan Pendidikan Bahasa Inggris \\ Universitas Pendidikan Ganesha \\ Singaraja, Indonesia \\ e-mail: gungtiknara@gmail.com¹, yayasurya8@yahoo.com¹, karina.wedhanti@undiksha.ac.id
}

\begin{abstract}
Abstrak
Penelitian sinkronik ini dirancang dalam bentuk kualitatif deskriptif. Penelitian ini bertujuan untuk mendeskripsikan jumlah fonem yang terdapat pada Dialek Tegallinggah dan distribusinya. Penelitian ini difokuskan hanya pada fonem segmental. Tiga informan dari Tegallinggah Dialek dipilih berdasarkan dari kumpulan persyaratan dan kriteria standar yang telah ditentukan. Data dikumpulkan menggunakan dua daftar kata yaitu: Swadesh dan Nothofer. Data yang diperoleh dianalisis dan ditampilkan secara deskriptif. Hasil dari penelitian ini menunjukkan bahwa Tegallinggah Dialek memiliki 44 fonem dan tidak semua fonem memiliki distribusi yang lengkap (posisi awal, tengah, dan akhir). Fonem dapat diklasifikasikan menjadi: enam vocal, delapan diftong, sembilan belas konsonan dan lima konsonan kluster, 4 geminates.
\end{abstract}

Kata kunci: fonologi, fonem, fonem segmental, vokal, konsonan.

Abstract

This synchronous study was designed in a descriptive qualitative form. This study was designed to describe the number of phonemes needed in the Tegallinggah dialect and its distribution. This study only supports segmental phonemes. Three informants from Tegallinggah Dialek were selected based on a set of predetermined standard requirements and criteria. Data was collected using two word lists namely: Swadesh and Nothofer. The data obtained were analyzed and collected descriptively. Tegallinggah Dialect has 44 phonemes and not all phonemes have a complete distribution (initial, middle and end positions). Phonemes can be played into: six vowels, nineteen consonants, five cluster consonants and 4 geminate, eight diphthongs.

Keywords: phonology, phonemes, segmental phonemes, vowels, consonants. 


\section{INTRODUCTION}

Language is essentially a means of communication among the members of a society (Sirbu, 2015). It is one of important tools used by human since it is used to communicate in daily life. While using language, people usually convey their feelings, ideas, and feeling in order to be understood by others.

According to Sirbu (2015), language can be used as identity of some groups. One of language system that can be characterized particular group known as dialect. Frasncis (as cited in Elfenbein et al, 2007) argued that Dialects are the variants or varieties of a language used by different speakers who are separated by geographic or social boundaries. The varieties can be seen in terms of vocabulary, grammar and as well as pronunciation.

One of language which has more than one dialect is Balinese language. there are two dialects found in Bali, namely; Bali Aga and Bali Dataran (Bawa and Jendra, 1981). These two dialect can be distinguished by the level of politeness. According to Antara (2011), Bali Dataran dialect has sor singgih basa or Politeness level which includes in the eight regencies of Bali such as Karangasem, Klungkung, Bangli, Gianyar, Badung, Tabanan, Jembrana, and Buleleng. On the other hand, Bali Aga does not have any sor singgih basa where existing in the regions of Nusa Penida, Bugbug, Tenganan, Seraya, Sembiran, Bintang Danu, Selulung, Pedawa, Cempaga, Sidatapa, Tigawasa, Mayong, Bantiran, Belimbing.

Tegallinggah Dialect is one of examples in diversity of Balinese language. this dialect belongs to Bali Dataran dialect.Balinese Language spoken by moslem people in Tegallinggah have different charracteristics. This differences can be seen in terms of vocabulary and pronunciation. There are several vocabularies only used by Muslim people in Tegallinggah e.g "Budi kija?" it refers to ask someone where they will go, commonly Balinese people will say "Lakar kija?". In term of pronunciation, Muslim people in Tegallinggah mostly use vocal [o] e.g. [k^lon] 'Necklace', [sot] 'tie'. The language used was affected by the use of Balinese Language mixed with their culture.

Due to the uniqueness of the use of Balinese Language in Tegallinggah by Moslem people and there are no written data or document about Tegallinggah dialect yet, it is interesting to conduct a research about the Tegallinggah dialect. The study will be focused on identifying the phonological system of Tegallinggah dialect which includes the segmental phoneme of Tegallinggah dialect, namely: vowels, consonants, consonant clusters, diphthongs, triphthongs, and geminates. It seems to be important because phonological system of each language or dialect is different. Seken (2017) stated that Phonology is an analysis that deals with the structure and function of speech sound in conveying meaning. Meanwhile, Roediyanto (1983)stated that phonology is the study about the concrete characteristic (articulatory, auditory and acoustic) of the sound used in a language. From these two explanations, we can conclude that Phonology is a study about speech of sound which occurs in Language. So, this research is worth to be conducted, in order to know about the phonological system of Tegallinggah and give Tegallinggah Village its' credit of its own treasure. 


\section{Method}

This research was designed in a form of descriptive qualitative method. The subjects of the research were Tegallingah people who gave information related to the data needed. There are 2 types of informants used, namely; the main informant and secondary informants. The main informant was a person who gave accurate information needed by the researcher while the secondary informant supported the information given by the main informant. The informants were selected based on a set of criteria suggested by Samarin (as cited in Budasi, 2016)

The objects of this study are the phonological system of Tegallingah whih describe the phonemes exist in Tegallinggah Dialect. The phonemes involved vowel, diphthongs, consonants, consonants cluster, geminates.

The data were gained through observation, recording, and interview technique. The instruments in this study were the researcher, wordlist (Swadesh and Nothofer), observation sheet, recorder, and camera.

The obtained sata were analyzed through 3 process, namely; Data Reduction, Data Display, and Data Conclusion/ Verification (Miles and Huberman, 1984).

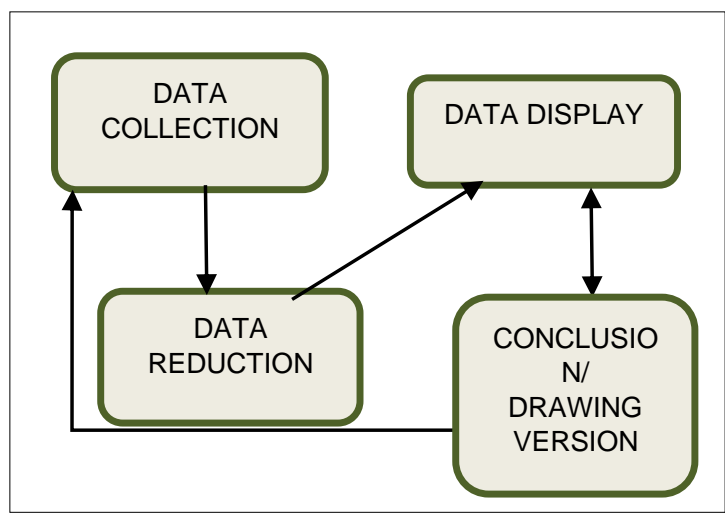

Figure 1: Interactive Data Analysis Model

(Mahsun, 2005)

In data reduction, the data were selected and simplified. the data were transcript data needed such us transcript the word list and recording.

The next step was data display where the data were classified into segmental phonemes and put it on the table distribution.

The last was verification which involved drawing meaning from displayed, reduced datanoting regularities, patterns, explanations, possible configurations, causal flows, propositions. These conclusions are also verified, tested for their plausibility, robustness, sturdy-ness, and validity.

Sugiyono (2008) stated that Triangulation is the process of checking the validity and reliability through various sources. This study uses the techniques of triangulation which used to test the validity of the data by checking through different techniques such as observation, interview, and recording. According to Denzin (1970) there are three types of data triangulation, namely: time triangulation, space triangulation, and person triangulation. However, this study only applied two types of triangulation

Time triangulation refers to time in obtaining data. In this study, the researcher collected the data in different times. It aimed to see the same data always appeared and find out new data. 
Person triangulation means the researcher collected the information from several people in Tegallinggah village that can give accurate data.

\section{FINDING AND DISCUSSION}

This study found 44 phonemes in Tegallinggah Dialect. These phonems were distributed into three parts, namely; initial, medial, and final. These phonemse are classified into vowel, diphthong, triphthongs, consonants, consonant cluster, and geminates.

\section{Vowels}

There are 6 vowels found in Tegallinggah Dialect, namely; / $/ /, / \mathrm{I} /, / \mathrm{u} /, / \mathrm{E} /, / \mathrm{o} /$, and $/ \cong$. Among the 6 sounds, 3 of them have allophone. The allophone of the phonemes are: [i:] and [I] which are the allophone of /i/. [u:] and [Y] are the allophone of /u/. [O:] and [O] which are the allophone of $/ \mathrm{o} /$. so, it can be said that there are 9 vocoids in Tegallinggah Dialect, namely: $[\Lambda],[\mathrm{I}],[\mathrm{i}:]$, [ ],

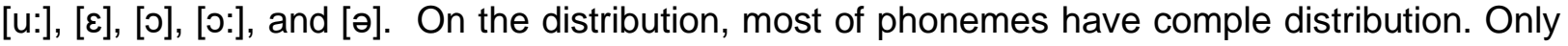
vowel / $N$ / have incomplete distribution. This vonem only appears at initial and middle. example;

\begin{tabular}{|c|c|}
\hline Initial & Middle \\
\hline 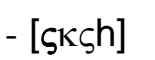 & $-[\pi \zeta d \zeta N]$ \\
\hline 'root' & 'grass' \\
\hline$-[\varsigma \mathrm{W} \varsigma \nu]$ & $-[\lambda \varsigma \lambda \varsigma h]$ \\
\hline 'cloud' & 'hot' \\
\hline \multirow{2}{*}{$\begin{array}{l}-[\varsigma \mathrm{d} \cong] \\
\text { there' }\end{array}$} & - $[\gamma \varsigma \mid \varsigma N]$ \\
\hline & 'light’ \\
\hline
\end{tabular}

\section{Diphthongs}

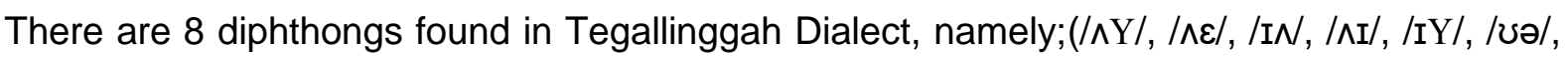

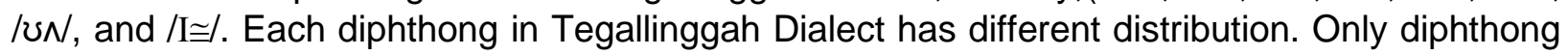
$/ \varsigma \mathrm{I} /$ has complete distribution in initial, medial, and final position where the rest of the diphthong

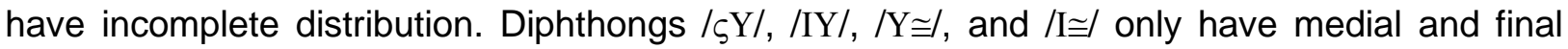
distribution; diphthong $/ \mathrm{Y}_{\varsigma} /$ only has initial and medial distribution while diphthong / $\varsigma \mathrm{E} / \mathrm{and} / \mathrm{I} \varsigma /$ only have one distribution in final or medial.

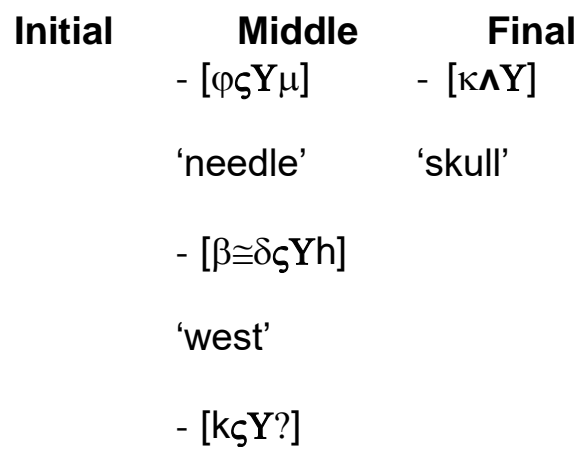


'calling'

\section{Triphthongs}

There are no triphthongs phoneme found in Tegallinggah Dialect. The researcher jump to this conclusion after observing the data obtained and based on the theory, it can be said there are no triphthong appear in this dialect.

\section{Consonant}

There are 19 consonants found in Tegallinggah Dialect, namely; /b/, /c/, /d/, / $/ /, / \mathrm{h} /, / \mathrm{j} /, / \mathrm{P} /$, $/ \mathrm{k} /, / \mathrm{l} /, / \mathrm{m} /, / \mathrm{n} /, / \mathrm{p} /, / \mathrm{r} /, / \mathrm{s} /, / \mathrm{t} /, / \mathrm{w} /, / \mathrm{y} /, / \mathrm{h} /$, and $/ \tilde{\mathrm{n}} /$. Among 19 consonant, there are 12 consonants which have complete distribution (initial, medial, and final) . those consonants are $/ \mathrm{p} /, / \mathrm{b} /, / \mathrm{t} /, / \mathrm{d} /, / \mathrm{g} /, / \mathrm{s} /, / / /, / \mathrm{h} /, / \mathrm{m} /, / \mathrm{n} /, / \mathrm{N} /$, and $/ \mathrm{r} /$. while the rest of the consonants have incomplete distribution. Consonant $/ \mathrm{k} /, / \mathrm{c} /, / \mathrm{j} /, / \tilde{\mathrm{n}} /, / \mathrm{w} /, / \mathrm{y} /$ only appear in initial and final. Consonant /?/ only appears in final position.

\begin{tabular}{|c|c|c|}
\hline $\begin{array}{l}\quad \text { Initial } \\
-\left[p_{\varsigma} \vee \varsigma ?\right]\end{array}$ & 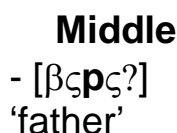 & $\begin{array}{r}\text { Final } \\
-[N \cong t \cong p]\end{array}$ \\
\hline 'child' & $\begin{array}{l}\text { - [kOpIN] } \\
\text { 'ear' }\end{array}$ & 'cut' \\
\hline$-[p \varsigma \lambda \cong]$ & - [ksupId] & $-[\eta \cong \pi S \cong p]$ \\
\hline $\begin{array}{l}\text { 'shoulder' } \\
\text { - [p }[\mathbf{p} \delta \varsigma \mathrm{s}] \\
\text { 'grass' }\end{array}$ & 'WIng' & $\begin{array}{l}\text { 'sipping' } \\
\text { - [NYssp] }\end{array}$ \\
\hline & & 'stroking' \\
\hline
\end{tabular}

There are 7 consonant clusters found in Tegallinggah Dialect. Those consonant cluster can be classified into 2 types of blend. The first is consonant cluster $/ \mathrm{r} /$ which can be blend with consonant $/ \mathrm{p} /$ and $/ \mathrm{k} /$ so it produces consonant clusters $/ \mathrm{pr} /$ and $/ \mathrm{kr} /$. The second is consonant cluster $/ \mathrm{l} /$ blended with consonant $/ \mathrm{k} / / \mathrm{m} /, / \mathrm{g} /, / \mathrm{b} /$, and $/ \mathrm{t} /$. the consonant clusters produced are $/ \mathrm{kl} /, / \mathrm{ml} /, / \mathrm{gl} /, / \mathrm{bl} /, / \mathrm{tl} /$. Consonant cluster $/ \mathrm{gl} /, / \mathrm{ml} /$, $/ \mathrm{tl} /$ only appear in initial postion, while consonant cluster $/ \mathrm{kl} /$ and $/ \mathrm{bl} /$ can be found in initial and medial position.

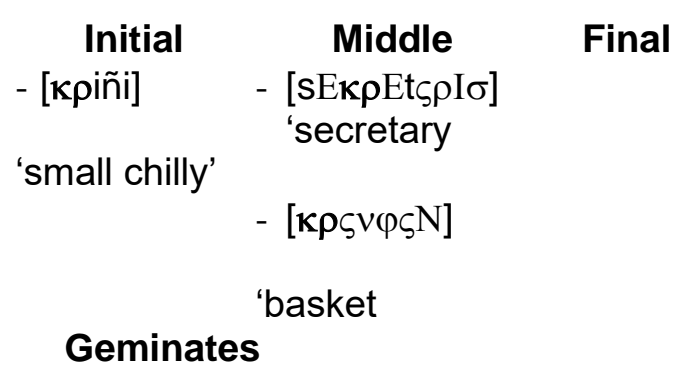

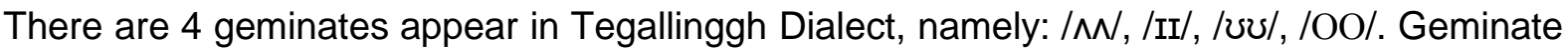
vowels found in Tegallinggah Dialect have incomplete distribution. Almost all geminate vowels only appear in the middle position while only /OO/ appear in the initial and middle position.

$\begin{array}{ccc}\text { Initial } & \text { Middle } & \text { Final } \\ & -[\mu \cong \delta \varsigma \varsigma \rho] \\ \text { 'eating' } & \end{array}$




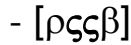

$$
\begin{aligned}
& \text { 'roof' }
\end{aligned}
$$

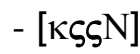

$$
\begin{aligned}
& \text { 'coral' }
\end{aligned}
$$

\section{Discussion}

The are 43 phonemes exist in Tegallinggah Dialect and those phonemes are: $/ \mathrm{N} / \mathrm{li} /, / \mathrm{u} /, / \varepsilon /$,

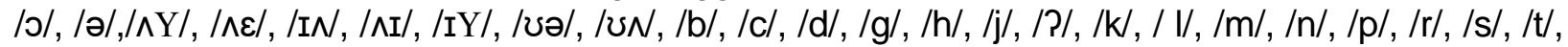

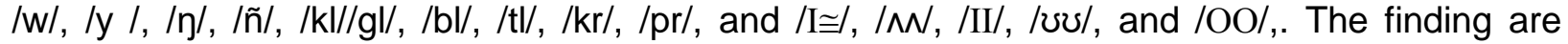
relevant to theory by Seken (2017) that states Phonemes is the smallest significant unit in the structure of language where it can contrast the meaning or make a difference meaning.

There are 6 vowels found in Tegallinggah Dialect and those vowels are: $/ \mathrm{N} /, / \mathrm{i} /, / \mathrm{u} /, / \varepsilon /, / \mathrm{J} /$, and /ə/. Three of those vowels have allophones. [I] and [i] are allophone of /i /. [v] and [u:] are allophone of $/ \mathrm{u}: /$ and the last one is [0] and [0] are allophone of of $/ \mathrm{o} /$. there are 4 vocoids which have This result is in line with Sistadi (2016) who conducted a study about phonological system of Kecicang Islam Dialect which also found 6 vowel exist in kecicang dialect and 3 of those vowels have allophones.

There were only 8 diphthongs found in Tegallinggah dialect. Those are $/ \wedge \mathrm{Y} /, / \wedge \varepsilon /$, /I $/$, / / I/,

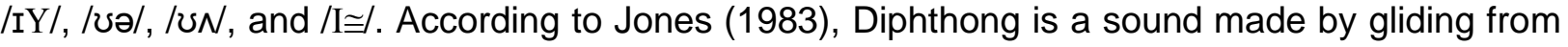
one vowel position to another. It is represented phonetically by sequences of two letters, the first showing the starting point and the second indicating the direction of movement. This theory becomes a consideration for researcher to classified the diphthongs

Triphthong is a combination with three vowels in one syllable (Roediyanto, 1983). Based on the theory of triphthong, the researcher did not find any triphthong appear in Tegallinggah dialect which makes the researcher come with a conclusion that no triphthong phoneme is exist in Tegallinggah dialect.

There were 19 consonants (/b/, /c/, /d/, /g/, /h/, /j/, /P/, /k/, / l/, /m/, /n/, /p/, /r/, /s/, /t/, /w/, /y $/, / \mathrm{n} /$, and $/ \tilde{n} /$.$) exist in Tegallinggah dialect. The existence of these phonemes proved by$ using minimal pairs. Minimal pairs are pairs of words which are different in respect of only on segment (Gimson, 1970:45).

There were only 7 consonant clusters found in Tegallinggah dialect and they can be categorized into 2 types of blend. Those two types of blend are I-blends and r-blends. In Iblends, there are three phonemes namely: $/ \mathrm{kl} /, / \mathrm{ml}, / \mathrm{gl} /, / \mathrm{bl} /$, and $/ \mathrm{tl} /$. Meanwhile in $\mathrm{r}$-blends there are two phonemes namely: $/ \mathrm{kr} /$ and $/ \mathrm{pr} /$. All of consonant clusters in Tegallinggah Dialect have incomplete distribution. These findings is based on Roach (2000) who stated that consonant cluster is defined as a group of consonant without any vowel between them.

Geminate is defined as a term used in phonetics and phonology for a sequence of identical adjacent segment of a sound in a single morpheme (Crystal, 1991). Based on the explanation above, it can be said that there are two kind of geminates. The first one is consonant geminates and Vowel geminates. It is because both consonant and vowel are segment of sound and could appear in a single morpheme. So that, based on the theory above, there were 4 geminate vowels found in Tegallinggah Dialect and no geminates consonants. Those geminates are: / $/ \mathrm{N} /$, /II/, / $/ \mho / /$, and /OO/. 


\section{Conclusion}

Based on the findings and the discussions it can be concluded that there are 44 phonemes found in Tegallinggah Dialect. These phonemes will be explained below:

1. Vowels

Tegallinggah Dialect has 6 phonemes vowels: $/ \mathrm{N} / \mathrm{i} / \mathrm{i}, / \mathrm{u} /, / \varepsilon /, / \mathrm{J} /$, and $/ \ni /$. Three of those have allophones. [I] and [i:] are the allophone of $/ \mathrm{i}: / \mathrm{r}$ [U] and [u:] are the allophone of $/ \mathrm{u}: /$ and the last one is [D] and [0:] are the allophone of of $/ 0 \% /$

Almost all of the vowel phonemes have complete distributions (appear in initial, middle and final position). Only $/ 0: /$ have incomplete distribution. it only appears in middle and final position.

\section{Diphthong}

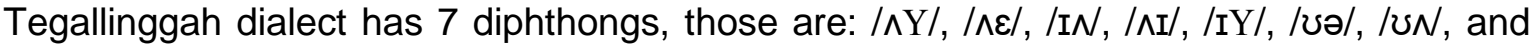
$/ \mathrm{I} \cong /$. Only diphthong $/ \varsigma_{\mathrm{I}} / \mathrm{has}$ complete distribution in initial, medial, and final position where

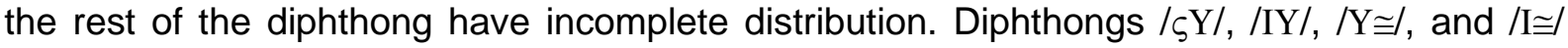
only have medial and final distribution; diphthong /uc/ only has initial and medial distribution while diphthong $/ \varsigma \mathrm{E} /$ and $/ \mathrm{I} \varsigma /$ only have one distribution in final or medial.

\section{Triphthong}

Tegallinggah Dialect does not have any triphthong phoneme. The researcher jump to this conclusion after analyzing the data and found there are no triphthong in Tegallinggah dialect. This conclusion also have been confirmed by the informants when the researcher did the confirmation about it.

\section{Consonant}

Tegallinggah Dialect has 19 consonants (/b/, /c/, /d/, /g/, /h/, /j/, /P/, /k/, / l/, /m/, /n/, /p/, /r/, $/ \mathrm{s} /, / \mathrm{t} /, / \mathrm{w} /, / \mathrm{y} /, / \mathrm{h} /$, and $/ \tilde{\mathrm{n}} /)$. 12 consonants $(\mathrm{p} /, / \mathrm{b} /, / \mathrm{t} /, / \mathrm{d} /, / \mathrm{g} /, / \mathrm{s} /, / \mathrm{l} /, / \mathrm{h} /, / \mathrm{m} /, / \mathrm{n} /, / \mathrm{h} /$, and $/ \mathrm{r} /)$ have complete distributions. Meanwhile the other 7 consonants do not have complete distribution. Consonants $/ \mathrm{k} /, / \mathrm{c} /, / \mathrm{j} /, / \mathrm{n} /, / \mathrm{w} /$, and $/ \mathrm{y} /$ do not appear in final position, and consonant $/ \mathrm{P} /$ only appear in final position.

\section{Consonant Cluster}

Tegallinggah Dialect has 7 consonant clusters and they can be categorized into 2 types of blend. Those two types of blend are I-blends and r-blends. In I-blends, there are three phonemes, namely: $/ \mathrm{kl} /, / \mathrm{ml} /, / \mathrm{gl} /, / \mathrm{bl} /$, and $/ \mathrm{tl} /$. Meanwhile in $\mathrm{r}$-blends there are two phonemes, namely: $/ \mathrm{kr} /$ and $/ \mathrm{pr} /$. All consonant clusters found in Tegallinggah Dialect have incomplete distribution. The consonant cluster $/ \mathrm{kl} /, / \mathrm{ml} /, / \mathrm{pr} /, / \mathrm{gl} /$ and $/ \mathrm{tl} /$ only appear in initial postion, while consonant clusters $/ \mathrm{bl} /$ and $/ \mathrm{kr} /$ can be found in initial and medial position.

\section{Geminates}

Tegallinggah Dialect has 4 geminate vowels and no geminate consonant. Those geminate vowels are: $/ \Lambda \mathrm{N} / / \mathrm{II} /, / \mho \mho /$, and $/ \mathrm{OO} /$. The distribution of those geminate vowels are incomplete. 
They never appear in the final position and mostly appear in middle position. Only /OO/appear in the initial and middle position.

\section{Suggestion}

It is expected that this study can be a reference for the other researchers who have interest in linguistic study, especially phonology in conducting the same study and exploring another dialect to be compared with Tegallinggah Dialect. It was very interesting to explore Tegallinggah village since this dialect is quite different from the researcher's dialect and it could give many new experiences for the researcher, especially in researching a phonological system of a dialect. As this study is only focused on phonological system of the Tegallinggah Dialect, it is not impossible for other researchers to do a research in other field of linguistics such as morphological, syntactic, lexical, and semantic levels of Tegallinggah Dialect. However, the researcher also expects that this study can be continued by other researchers to explore more about Tegallinggah Dialect.

\section{References}

Bawa, I W. dan Jendra, I W. (1981). Struktur Bahasa Bali. Jakarta: Pusat Pembinaan dan Pengembangan Bahasa Departemen Pendidikan dan Kebudayaan

Denzin, N. (1970). The Research Act in Sociology. Chicago: Aldine.

Elfenbein, H. A., Beaupre, M., Levesque, m., \& Hess, U. (2007). Toward a Dialect Theory: Cultural Differences in the Expression and Recognition of Posed Facial Expressions. Emotion, 131-146.

Ferguson, A. (2010). Language, meaning, context, and functional communication. ECU Research Online.

Jick, T. D. (1979). Mixing Qualitative and Quantitative Methods: Triangulation in Action. Administrative Science Quarterly, 602-611

Lyon, J. (1981). Language and Linguistics: An Introduction. New York: Cambridge University Press.

Miles, M. B., \& Huberman, A. M. (1984). Drawing Valid Meaning from Qualitative Data: Toward a Shared Craft. Educational Researcher, 20-30 
Pike, Kenneth L. (1974). Phonemics: A Technique for Reducing Languages to

Writing. Ann Arbor: The University of Michigan Press.

Roach, Peter. (2000). English Phonetics and Phonology: A Practical Course. Cambridge: Cambridge University Press.

Roediyanto, Razak. (1983). A Course in Phonology. FKIP Udayana University Singaraja: Unpublished

Seken, I. K. (2017). Introduction to Linguistics: A Reference for Language Teacher. Depok: Rajawali Pers.

Sirbu, A. (2015). The significance of language as a tool of communication. "Mircea cel Batran" Naval Academy Scientific Bulletin, 405-406 